\title{
GLOBALIZÁCIÓ, HEGEMÓNIA ÉS A HARMADIK ÉVEZRED POLITIKAI ÚJJÁRENDEZÖDÉSE; EZEK EGYES REGIONÁLIS VONATKOZÁSAI
}

\author{
(Globalisation, Hegemony and the Political Rearrengement \\ in the Third Millenium, and Some Regional Aspects of Them)
}

\section{SEGESVÁRY VIKTOR}

Kulcsszavak:

nemzetállam decentralizáció regionalizáció kommunikációstechnológiák

A nyugati kultúrkörben évszázadok óta uralkodó politikai-intézményes forma, a nemzetállam, mára teljesen csödbe jutatt, s nem honositható meg a civilizációnkon kivil esố teriletek országaiban, mert ezekben a nemzet fogalma ismeretlen, és nem felel meg semmifúle társadalmi valóságnak. A világállant egy irreális ideologia szülötte, s halálos veszélyt jelent a mai demokráciák számára azáltal, hogy egyrészt elképzelhetetlenial megnövelné a távolságot a döntést hozók és a döntések súlyát viselök között. másrészt teljesen kiszolgáltamá a kisebbségeket a tỏbbségi csoportok, vagy egy hatalomra jutot kisebbség diktatórikus hatalmának. Az új évezred elmaradhatatlan politikai átrendezödésének szempontjából az egyetlen elfogadható megoldás tehát a nem terialeti, hanem kulturális alapokon nyugvó, kisebb egységek létrehozása, melyeknek müküdését és koordinálását a mai legfejlettebb információs és kommunikációs technológiák lehetōvé teszik.

Meg vagyunk gyözödve arról, hogy ma legföbb ideje új ösvényeket keresni, új megoldásokat találni a késői modernitás társadalmának problémáira. Ez különösen sürgősnek látszik a politikai szférában, ahol máig is a felvilágosodás, a francia és az azt követö forradalmak kora folyamán kialakult nemzetállamok keretében élünk. A világon szerteszórtan élö kisebbségek megoldhatatlan kérdése, a felkelések, polgárháborúk, belső viszályok, s a minden demokratikus államhatalmat fenyegető bürokratizálódás elkerülhetetlenné teszi, hogy egy nem-centralizált politikai elrendezödés formáit dolgozzuk ki a harmadik millenium századai számára.

A tanulmány tárgya egy olyan politikai rendszer viziója, amelyet a nemzetállamoknál sokkal kisebb egységek alkotnak, s amelyek együttmüködését és politikájuk összehangolását a ma rendelkezésre álló információs és kommunikációs technológiák teszik lehetővé. Ugyanakkor a politikai szféra ilyen módon való újrarendezödése a demokratikus stabilitás megerösítését is eredményezné, mert közelebb hozná egymáshoz a döntést hozókat és azokat, akik a politikai, gazdasági és társadalmi kérdésekben hozott határozatok következményeit viselik. Eltüntetné tehát azt a távolságot, amely elválasztja egymástól a döntést hozókat és az utca emberét.

Tudatában vagyunk annak, hogy a politikai rendszer jövőjére vonatkozó gondolataink és javaslataink sokakban, talán legtöbb olvasónkban, ellenérzést és elítélést fognak kiváltani, vagy legalábbis a virtuális kor egyik kuriózumának fogják tartani, hiszen a nemzetállamok léte mindennapi életünk szerves része lett évszázadok óta. Ezért hangsúlyozzuk azt, hogy a tanulmány tárgya nem más, mint a jövővel kapcsolatos egyes gondolatok felvetése, s legföbb célja az, hogy szokatlan kérdések felve- 
Segesváry Viktor : Globalizáció, hegemónia és a harmadik évezred politikai újjárendeződése; ezek egyes regionális vonatkozásai.

Tér és Társadalom 16. évf. 2002/4. 1-24. p.

2 Segesváry Viktor

TÉT XVI. évf. 2002

tésére és a mindennapitól eltérő gondolkodásra kényszerítsék azokat, akiket foglalkoztatnak a jelen politikai rendeződésének megoldhatatlan problémái.

A tanulmány három részböl áll:

Elöször a nemzetállam hanyatlásának tüneteit vizsgáljuk;

Másodszor a jövő politikai rendjének alkotóelemeit vázoljuk fel, előrevetítve e lazán összefüggö, kisebb politikai egységek jellegzetességeit;

Harmadszor az információs és kommunikációs technológiák kiemelkedő szerepét értékeljük, melyek ezeknek az egységeknek létrejöttét lehetővé teszik.

\section{A terïletileg meghatározott nemzetállam hanyatlása}

\section{A globalizáció jelentősége}

Témánk elöször korunk egyik alapvetö dialektikájának - a globalizáció és a kozmopolitizmus dialektikájának - keretében fogjuk elemezni. A világ globálissá válásának folyamata egy igen komplex, sok vetületet felmutató folyamat. Sajnos a médiákban és a közvéleményben csak egy nagyon szüken értelmezett felfogása uralkodik. A globális világ megértésének analízise négy, egyre táguló perspektívához vezet:

- Az elsô a gazdasági folyamatok leegyszerúsített képe, amely a pénzügyi piacok együttmúködésére és a világkereskedelemre vonatkozik. Ezt a változatot ennek megfelelően sokan a piac integrációjaként értelmezik. Eszerint a globalizáció a piac tevékenységének logikus és elkerülhetetlen következménye, s ezáltal egy önmagát megvalósító célt testesít meg. John Brohman megfogalmazásában: „A piac ideológiailag kidolgozott fogalma helyettesíti be a különféle, a történelem folyamán kialakult piacokat a világ különféle országaiban." (Brohman 1995, 314)

- A globalizáció második értelme egy mindenki által könnyen érzékelhető tömeges jelenség, amely a transznacionális (tehát nem nemzetközi) mozgalmak formájában jelenik meg.

- Kortársaink közül kevesen látják azt, hogy a globalizáció - a harmadik perspektívában - nem más, mint a nyugati civilizáció, s ennek különösképpen amerikai változata hegemonikus törekvése. A globalizáló folyamatnak ezt a formáját tulajdonképpen egy ideológiának lehet tekinteni, mert azon alapul, hogy korunkban ennek nincs alternatívája, ha más civilizációkhoz tartozó népek modernizálódni akarnak - egy ideológia, amelyet Theodore von Haue, a Yale egyetem volt professzora, 1988-ban megjelent könyvében „az elnyugatosítás világforradalmának" nevezett (The World Revolution of Westernization). Éppen ezért a globalizáció eme formájának a világkultúra és világ-civilizáció fogalmai szerves részei. Nagy-Britannia katonai akadémiája egyik professzorának, Simon Murdennek ez év nyarán megjelent tanulmánya (Islam, the Middle East, and the New Global Hegemony [Murden 2002]) rámutat ennek az ideológiának a kérdéses külpolitikai következményeire is, kü- 
Segesváry Viktor : Globalizáció, hegemónia és a harmadik évezred politikai újjárendeződése; ezek egyes regionális vonatkozásai.

Tér és Társadalom 16. évf. 2002/4. 1-24. p.

TÉT XVI. évf. 2002 - 4

Globalizáció, hegemónia és ... 3

lönösképpen a Közel-Keleten, átvéve John Agnew és Stuart Corbridge kifejezését a ,transznacionális liberalizmus hegemóniájára” vonatkozólag.

- Végül, a negyedik perspektívában, a globalizáció nem más, mint annak öntudatosodása, hogy e folyamatnak van egy elkerülhetetlen alapvetó vetülete, tulajdonképpen a globalizáció másik arca, a világban koegzisztáló civilizációk dialógusa. Ebben az értelemben a globalizáció egy, az összes „embervilágokat" egybefogó, planetáris látomással egyenlő. Ez azt jelenti, hogy bizonyos civilizációs vagy kulturális vonások elvesztik területi kötöttségeiket. Ugyanakkor a globalizációnak ez a felfogása helyet ad annak a jelenségnek, amely a globális hódításának egyenlőtlen voltára utal, vagyis arra, hogy a globális kiterjedése elsősorban hely, idö, társadalmi osztály és a társadalom által elfogadott életmód kérdése - mint pl. a harmadik világra vonatkoztatott , digitális hiány" divatossá lett jelszava. (Azt persze senki sem kérdezi, hogy az afrikai vagy az indiai paraszt szempontjából mit jelent ez a hiány?) Ezért van teljesen igaza Robert Coxnak, amikor úgy véli, hogy ,a világ jövö rendjét két alternatíva közötti választás dönti majd el: az univerzális globalizáció vagy a más típusú gazdasági, társadalmi és kulturális fejlődés közötti választás." (Cox 2000, 219)

A globalizációs folyamat eredményeképpen a különféle kontextusokban felmerülö identitások és jelenségek kimondottan összeszövődnek. A globalizációnak ezt a vetületét Roland Robertson fejezte ki mesterien 1992-ben megjelent alapvetỏ munkájában, amikor úgy jellemezte a globalizációt, mint a partikularizmus univerzálissá és az univerzalizmus partikulárissá válását, amely kölcsönös egymásra hatásuknak az eredménye (Robertson 1992, 100). Ez a robertsoni formula - véleményünk szerint - máig is a legjobb jellemzése a globalizálódó folyamatnak, mert egyrészt világosan rámutat a globális világban uralkodó univerzalista trendre - a nyugati konzumerizmus egész világra való kiterjedésére -, másrészt teljes mértékben elismeri az „embervilágok” különleges voltát és életstílusaik különbözöségét, mint pl. a nemzeti öntudat vagy más kollektív, kulturális identitások feléledését és globális felértékelödését. Amint Jürgen von Hagen kifejezte, népek, régiók, etnikai csoportok és kultúrák csak a különbségek elismerése révén tudják a maguk identitását meghatározni (Hagen 1998, 180).

Kulturális pluralizmus jellemez minden, a nyugatitól különböző civilizációt, ugyanúgy a múlt politikai rendszereit is, mint pl. a régi, multietnikus birodalmakat, s ez bizonyítéka annak, hogy más megoldások is lehetségesek a jövő politikai újjárendeződésére, mint a kozmopolitizmus által elörevetített világkultúra és világállam. Ezért ma is érvényes Hedley Bull értékelése a középkorra vonatkozóan, amikor annak alapvetỏ jellegét, a megosztott szuverenitás elvét és a „sokrétủ, egymást lefedö intézmények” és az "egymást keresztező" lojalitások lehetőségét emeli ki (Bull 1995, 254-255).

A globalizációs folyamat tehát hangsúlyozza a tér és a hely dialektikáját, s ezen keresztül a lokális bizonyos mértékben meghatározza a globálist. Ebben az értelemben a globalizáció egyre nyilvánvalóbbá teszi azt, hogy a hatalom, bármely hatalom, nem a területi megalapozottságon nyugszik, s nem egy egyedüli, privilegizált 
politikai intézményen - az államon -, hanem kulturális adottságokon és egyes konstitutív elemek egymástól való fủggésén.

\section{A területi nemzetállam hanyatlása}

Ha a területiség egy közösség életének fizikai jellemzője, akkor e közösség identitásának is része. A modernitás korában az emberek viszonya a területhez, amelyen élnek, teljesen megváltozott abban az értelemben, hogy identitásukban a területiség szerepét az állam vette át, mert az állam lett a területiség elvének kifejezője, s a határok végeredményben szimbolikus jelentöséget nyertek. Ugyancsak ennek a fejlődésnek a következményeként egy állam lakosságának identitásában külön helyet kapott államuknak az államközi rendszerben elfoglalt helye. Az államközi rendszer befolyása viszont gyengítette a területi állam szerepét.

A nemzetállam politikai intézményes formájának válságát egypár fontosabb vonással szeretném illusztrálni. Összehasonlítva a modern korban kialakult helyzetet az előzőleg uralkodó viszonyokkal, meg kell állapítani, hogy a nem-modern társadalmakban a terület nem játszott szerepet a politikai rendszer felépítésében, mert az adott kulturális keretben a terület a társadalmi közösség tulajdona volt. Az uralkodó vagy törzsfönök adminisztrálta közössége nevében az általuk bírt területet, $\mathrm{s}$ ez utóbbi nem lett a nép kulturális identitásának integráns része. Ezzel szemben a késői középkor Európájában a fejlődés a rokonsági és húbéri kötelékekre alapozott társadalmi viszonyok helyett egy komplex, hierarchikusan felépített társadalom felé haladt, melyben a területiség meghatározott határokkal körülvett térséggé vált, bár ez még nem feltétlenül jelentette a területileg megalapozott modern állam megszületését. A területiség a modern fejlödésnek ebben az elsó szakaszában egy adminisztratív fogalmat alkotott, kijelölve a feudális környezetből magát kiemelö uralkodó hatalmának határait, de a modern nemzetállam beköszöntével az állam meghatározott területe a nemzeti identitás elválaszthatatlan részévé vált.

Persze ez nem azt jelenti, hogy a modernitás beköszönte elött nem voltak határok, hiszen a területi elhatároltságok nemcsak politikai, hanem társadalmi szerepet is játszanak, például egyes közősségek elkülönítését vagy összekötését szolgálják, mint ahogy ez történt Afrikában évezredek óta, a különféle tereket áthidaló zónák esetében. A modernitás eljövetele tehát egy bizonyos fajta kozmopolitizmust tüntetett el izolálva az egyes politikai egységeket egymástól. Exkluzív fennhatóság a határokon belül, függetlenség a határokon túl lévökkel szemben - ezt jelentette a nemzetállami szuverenitás.

A nemzetállamok határai elméletben a nemzeti közösségek kiterjedésének határaival estek egybe. Ez lett az újkor minden nacionalista mozgalmának célja, annak ellenére, hogy alig volt olyan nemzet, amelynek tagjai egy kompakt területen éltek volna. Az etnikai kötelékeket, amelyek kimondottan kulturálisak, egy politikai elkötelezettség egészítette ki, a saját államával bíró politikai nemzet fogalma. Ahogy Bertrand Badie, a párizsi Politikai Tudományok Intézetének professzora, világosan megfogalmazta: 
Segesváry Viktor : Globalizáció, hegemónia és a harmadik évezred politikai újjárendeződése;

ezek egyes regionális vonatkozásai.

Tér és Társadalom 16. évf. 2002/4. 1-24. p.

TÉT XVI. évf. 2002 - 4

Globalizáció, hegemónia és ...

5

„A territorialitás elvének elterjedése nem az univerzális győzelmét jelentette a partikuláris fölött, csak egy univerzálisnak látszó elv formájába öntötte a világot meghódító partikuláris követelményét." (Badie 1995, 53)

A modern államnak feltétlenül szüksége volt arra, hogy lakosait nemcsak állampolgári viszonyuk kösse az államhoz, hanem az etnikailag és kulturálisan meghatározott nemzetben való tagsági voltuk is, másképpen nem tudta legitimitását érvényesíteni, és a népesség lojalitását biztosítani. A Hobbes, Locke és Rousseau által a 18. században kidolgozott kontraktuális elmélet - amely szerint a lakosság tagjai egy mindkét fél számára kötelezö, társadalmi szerződés keretében átruházták szuverenitásukat az államhatalomra - egy intellektuális fikció minden reális alap nélkül (Niebuhr 1965, 55-56). Legújabban Friedrich Kratochwil professzor analizálta részleteiben a társadalmi szerződés elméletét (Kratochwil 1996, 183), s az ô kritikája szerint a társadalmi szerződés legitimitását csak az állam territoriális hatalmára lehet alapozni. A demokráciák krízise a nemzetállam hanyatlásának egyik legfőbb vonása. Jürgen Habermas már 1975-ben „legitimációs krízisről" írt (Habermas 1975, 36-37), éppen azért, mert az állam és a civil társadalom közötti egyre mélyedỏ szakadékot jelzi. Egyébként az is figyelemre méltó, hogy az önrendelkezés jogát, amely a demokratikus jogoknak el nem kerülhetö része, csak a gyarmati sorsból felszabadult népek javára ismerték el az államközi rendszer tagjai a második világháború után, de azokra a kisebbségekre, amelyek szuverén államokban éltek, elsösorban az európai kontinensen, ezt az alapvetỏ demokratikus követelményt elfelejtették alkalmazni. A szuverén, területileg meghatározott nemzetállamok vesztfáliai rendszerének a múlt hagyatékává való válása tehát integráns része a globalizálódó világnak, s egy poszt-vesztfáliai rendszer kezd lassan-lassan kialakulni, amely nem területileg meghatározott politikai és gazdasági egységekböl fog állni. Amint ezt Anthony McGrew kifejezte, ,a demokratikus felelösséggel való felruházás területi bázisa már nem felel meg feltétlenül a hatalom térbeli kisugárzásának" (McGrew 1997, 12-13, 21), mert a globalizáció túlhaladottá teszi a nemzetállamok politikai rendszereit.

A politikai újjárendezödés szükségességét igazolja a civilizációs pluralizmus is. A civilizációk nem területileg, hanem egzisztenciálisan és kulturálisan meghatározott „embervilágok,” melyeket egymástól különböző spirituális, intellektuális, müvészi és tudományos teljesítmények, valamint egymástól eltérő társadalmi szokások és tevékenységek jellemeznek. Amint Camillieri és Falk megfogalmazták, a jövő civil társadalmait egyidejüleg „,két lehetséges és egymással ellenkező trend fogja jellemezni: a kulturális identitások megújult fontossága és a kulturális pluralizmus elfogadása" (Camillieri-Falk 1992, 255). A világállam létrehozásának tehát nem a nemzetállamok elhalványuló szerepe, nem a föderalista törekvések, mint az Európai Unió, nem a jelenlegi hegemónikus államközi rend a legfőbb akadálya, hanem a földünkön koegzisztáló nagy civilizációk léte, melyek alapvetően meghatározzák minden egyes egyén egzisztenciáját.

Mindezekkel a különbségekkel azonban nem számolnak a világállam létrehozásának hívei. Ennek az illuzórikus és megvalósíthatatlan megoldásnak a szükségessé- 
Segesváry Viktor : Globalizáció, hegemónia és a harmadik évezred politikai újjárendeződése;

ezek egyes regionális vonatkozásai.

Tér és Társadalom 16. évf. 2002/4. 1-24. p.

6

Segesváry Viktor

TÉT XVI. évf. 2002

gét elsősorban az örök emberi álomra alapozzák, amely a különféle „,embervilágok” egyesítését képzeli el, s a globalizáló trend lényegének félreértése folytán azt hiszik, hogy az álom megvalósításának órája elérkezett. A világállam létrehozását az emberi teremtőerő és képzelet teljes elhanyagolásával, kizárólag a nemzetállam intézményes struktúráinak és funkcióinak planetáris megismétlésével képzelik el. Eszükbe sem jut ennek végzetes következménye a demokratikus rendszer létére vonatkozóan, mely minden várakozás ellenére megsemmisülne, és a legnagyobb politikai, gazdasági és társadalmi nehézségekhez és krízisekhez vezetne.

\section{Egy nem-centralizált demokratikus politikai elrendezödés föbb vonásai}

Nem-centralizált politikai egységekröl beszélünk, mert ha a decentralizált kifejezést használnánk azzal feltételeznénk egy centralizált egység létét - amint ma egyes szövetségi államok decentralizált rendszeréröl szólunk. Szóhasználatunk Henry Kissinger pár évvel ezelőtt elhangzott megállapításának végső következtetését vonja le, amelyben a volt amerikai külügyminiszter a decentralizációt a demokrácia legmagasabb fokának minősítette.

Az új politikai szervezetek és intézmények egy, a mai állam fogalmával egyáltalán nem egybeeső politikai egységeket fognak alkotni. Ezeket, mint kisebb vagy nagyobb régiók hálóját - networkjét - lehet elképzelni, melyek lazán függenek össze, de egy koordináló központhoz kapcsolódva minden tevékenységüket össze tudják hangolni. Képük tehát megfelelne a folytatólagos kormányzási kontinuum elvének, az Arend Lijphart (Lijphart 1977) által propagált konszenzusra épülve, vagy a középkorihoz hasonló konszociális demokráciák formájában. Ezeknek az egységeknek az eredetisége és autonómiája egy meghatározott kulturális kontextushoz fog kapcsolódni, egy szélesebb civilizációs keretben, egy korlátozout szuverenitás formájában, de egy új multilateralizmust megvalósítva, melynek keretében a civilizációk közötti dialógus létrejöhet.

\section{Az új egységek konstitutív elemei}

Ezeket a politikai intézményeket kulturális, etnikai-nemzeti és vallási közösségek hoznák létre, sok esetben több, egymással harmóniában élö közösség. Még a múlt században is voltak jó példái annak, hogy egy ilyen békés együttélés lehetséges különféle közösségek között. Gondoljunk pl. Boszniára, ahol ortodoxok és muzulmánok egy sokrétegú kulturális egységet alkottak, mielött a szerb és horvát nacionalizmusok nem hiúsították meg békés együttélésüket. Meg vagyunk győzödve arról is, hogy Erdélyben a magyarok és románok egy pluralista és autonóm politikai szervezet keretében együtt tudnának élni. Mindez pontosan azért lesz lehetséges, mert az uniformizálásra való törekvések a múlt emlékei lesznek, hiszen a nemzeti szuverenitás zászlójára irrt „egy állam, egy nemzet” jelszava eltünik a tömegek szótárából. 
Segesváry Viktor : Globalizáció, hegemónia és a harmadik évezred politikai újjárendeződése; ezek egyes regionális vonatkozásai.

Tér és Társadalom 16. évf. 2002/4. 1-24. p.

TÉT XVI. évf. 2002 a 4

Globalizáció, hegemónia és ...

7

Hivatkoznunk kell itt a régiók tudományos tanulmányozása svéd specialistájának, Björn Hettnének nézeteire is. Hettne kifejezetten aláhúzta a régiók és a kulturális pluralizmus összefüggését a modern társadalomtudományokban nagy szerepet játszó funkcionalizmussal szemben. Hettne a régió alatt országok olyan csoportját érti, amelyeknek egy közös politikai programjuk van, s ebből a kulturális perspektívából vezeti le a politikai intézményesítést. Finn gondolkodók, mint Anssi Paasi és Jouni Hakli, a régiónak ugyancsak kollektív és intézményes jelleget tulajdonítanak, melynek szimbolikus jelentőségét az adja, hogy ,a tér és idő specifikus kapcsolatának és struktúrájának kifejezése" (Hakli 1994, 28).

Perspektívánkban regionalizmus és regionalizáció között teszünk különbséget. Regionalizmus alatt egy sui generis jelenséget értünk, egy, a lakosság köréböl eredö kezdeményezést a regionális együttműködés megteremtésére, mely végeredményben annak felel meg, amit e témakörben javaslunk; míg a regionalizáció egy regionális együttmüködés megteremtése a nemzetállamok kormányainak kezdeményezésére - mint az Európai Unió. A regionalizmus része egy globálizálódó világ több dimenziós képletének, már csak azért is, mert mindkettőben többszörösek a politikaihatalmi struktúrák. Így a regionalizmus, amely a civil társadalom kezdeményezése, nyitott a környezỏ világ felé, amelyhez az élenjáró technológiák révén kapcsolódik.

Még azt is el lehet képzelni, hogy egy bizonyos egységhez tartozó közösségek nem laknak összefüggő területeken, hanem több részböl - régiókból vagy egyes régiók külöféle közösségek által lakott részeiböl - tevởnek majd össze. Ezt a lehetőséget már a kanadai David Elkins is feltételezte, aki kondominiumról vagy „,szabályozott anarchiáról" írt pár éve megjelent munkájában (Elkins 1995, 145). Elkins szerint:

„Nem-exkluzív és nem-összefüggő területek a területiség felnyitását jelentik ... Egy nem territoriális szervezet sokkal több hajlékonysággal bír, mint bármely territoriális szervezet ... ilyen esetekben a szervezeti struktúrákat kevésbé hierarchikusnak lehet elképzelni, vagy sokrétü hierarchiákat lehet feltételezni, amelyeket inkább egy hálózatnak vagy networknek lehet minösíteni" (Elkins 1995, 139-140).

Nyilvánvalóan egy ilyen helyzetben az egyes egységek politikájának koordinációja rendkívüli módon fontos. Egyébként a nem-centralizált politikai rendezödés elleni legmeggyőzőbbnek látszó kifogás természetesen az, hogy a centralizáció a harmonizált és egymást kiegészítö politikai döntések miatt szükséges - hozzáadva ennek elkerülhetetlen voltát a mai hatalmas népességủ országokban. Mondanunk sem kell, hogy a környezetvédelem, a rendelkezésre álló munkaerő piaca, a gazdasági infrastruktúrák, úm. utak, hidak építése és fenntartása például, vagy a világszerte terjeszkedỏ bủnözö tevékenységek - kábítószerek kereskedelme, prostitúció, pénzhamisítás stb. - visszaszorítása mind csak közösen keresztülvihetö feladatok.

Pontosan ezen a téren nyernek hallatlan jelentőséget a ma rendelkezésünkre álló információs és kommunikációs technológiák, melyek az új politikai egységek regionális és szubregionális központjait kötnék össze, felhasználva a kommunikációs feedback által nyújtott lehetőségeket. Minden ilyen központ egy meghatározott 
Segesváry Viktor : Globalizáció, hegemónia és a harmadik évezred politikai újjárendeződése;

ezek egyes regionális vonatkozásai.

Tér és Társadalom 16. évf. 2002/4. 1-24. p.

területet fedne le, s a problémák természete szerint - többek között szektorális, környezetvédelmi, szociális, nevelésügyi vagy bevándorlási problémák - lenne megszervezendő. Személyzetük korlátozott számú, de kitünő képességekkel rendelkező személyekböl állna, s tevékenységükre egy, az általuk koordinált egységek képviselöibỏl álló bizottság ügyelne fel.

\section{Törvényhozás és kormányzás}

Az új egységek törvényhozási szervei, ha egyáltalán lesznek ilyenek, helyi, egykamarás gyülésekböl fognak állni, de a legfontosabb döntések meghozatalában lehetséges lenne az érdekelteknek, tehát a lakosságnak a véleményére is támaszkodni referendumok útján. Ezeket igen megkönnyítené a mai technológia eszközeinek kiterjedt alkalmazása, hiszen ma már több helyen is kísérleteznek az elektronikus szavazás vagy véleménynyilvánítás megszervezésével. A kormányzási és igazgatási szervek nemcsak konzultálni tudnának, amikor erre szükség lenne a lakosság egészével vagy annak egy érdekelt részével, hanem a feedback révén rendszeresen kaphatnának véleményeket, az egyes intézkedéseknek a valóságban elért eredményeire vonatkozó jelentéseket, sőt még egyesek tiltakozását is.

Visszatérve Lijphardt konszociális, vagyis konszenzusra épített demokratikus államának jellegzetességeihez, ezek alkalmazása kisebb vagy nagyobb egységekre egyaránt lehetséges. Ebben a vonatkozásban meg kell emlékeznünk Szücs Jenő tanulmányáról, Vázlat Európa három történeti régiójáról, melyböl kitünik, hogy az írásunkban javasolt nem-centralizált politikai intézményeknek elöfutára volt az európai feudalizmus kora:

„Mindezeken túl a hübériség territoriális következménye, a sok-sok kis, saját szokásjoggal élő tartomány, az interkommunikáció adott szintjén sokkal alkalmasabb talaj volt a közvetlen jogszerüség kifejlödésére és a jog mint szokás (mos terrae) minuciózus érvényesülésére, mint a nyersen és felülröl tagolt, elnagyoltan tágas és uniformizált politikai-kormányzati keretek. Ez volt az a közeg, mely lehetővé tette, hogy a jog és kormányzat 'alulról felfelé' ható elvei a lokális szinteken minél több ponton áttörjenek a hatalomgyakorlás 'felülrỏl lefelé' érvényesülő mechanizmusán ... A kifejlett hủbérszerkezetben az államigazgatási, katonai, fiskális, bíráskodási funkciók szintén maradéktalanul elszakadtak az uralkodó hatalomtól, hogy lesüllyedve mintegy lépcsözetesen eloszoljanak a 'hübértársadalomban', ahol aztán minden szinten külön-külön integrálódtak, egybeolvadva a földbirtoklás ugyancsak lépcsőzetes rendszerével ... A 'szabadság kis köreinek sokasága,' amiben Bibó István joggal látta a nyugati fejlödés alapvetését, végeredményben a maga territoriális és rendi tagoltságában is néhány alapmodell köré szervezödött; a sokaságban az egység abban állt, hogy hovatovább a 'szabadságjogok' váltak a struktúra belső szervező elvévé." (Lijphardt 1977, 31-32)

Ez az idézet is mutatja, hogy az itt javasolt politikai újjárendezödés, különösképpen a nem-centralizált elv alkalmazása, nem újdonság a történelemben. A többségi 
Segesváry Viktor : Globalizáció, hegemónia és a harmadik évezred politikai újjárendeződése; ezek egyes regionális vonatkozásai.

Tér és Társadalom 16. évf. 2002/4. 1-24. p.

elvre épített demokratikus rendszerrel teljesen ellenkezö a centralizmus elve - nincs demokratikus centralizmus -, s a mai demokráciák elsősorban a bürokratikus centralizmus fellegvárai. Végeredményben ennek a bürokratikus centralizmusnak a megszüntetése elkerülhetetlen feltétele a demokrácia megfelelő működésének, mivel

1) Egy nem-centralizált intézményes struktúra, amely a döntéseket meghozó hatalmat visszajuttatja a helyi hatóságokhoz és a lakossághoz, kizárja a bürokrácia beavatkozását milliók életébe pontosan azért, mert a közügyek személytelen elintézésének vet véget, és

2) A nem-centralizált intézményes struktúra biztosítaná a szubszidiaritás elvének következetes alkalmazását. Ennek az elvnek az alkalmazását hiába várjuk azoktól, akiknek a hatalma kiterjed nagy területek számtalan lakosára, s akiknek ez persze nem érdeke. Az érdekelt lakosok maguk vennék kezükbe a döntések jogát kisebb egységek keretében. Így a döntések demokratikus legitimitással bírnának, mert ahogy Lynn Miller megfogalmazta, ,a legjobb társadalmi rend csak a kiterjedt helyi ellenörzéssel és politikai autonómiával egyeztethetö össze, amely ugyanakkor összekötne mindenkit a társadalmi szolidaritás globális networkjében" (Miller 1994, 89).

Az adóügyi adminisztráció és a jóléti rendszer problémáinak megoldásában lehet a szubszidiaritás elve alkalmazásának legjobb példáira utalni. Röviden: az adóügyi politikának a célja kizárólag a helyi szükségletek kielégítése lenne, s a bevételi forrásokat ehhez igazítva lehetne megállapítani. Míg a jóléti redszerben nemcsak a helyi, kisebb közösségekben lehetséges kontrollok járulnának a kiadások lecsökkentéséhez, hanem - s ez a legfontosabb - a hatóságok beavatkozása nélkül a lakossági szolidaritás segítene egyes szerencsétlen helyzetek és bajok orvoslásában vagy állandó szociális nehézségek rendezésében is.

Itt kell szólnunk a jogi pluralizmus kérdéséröl is, amely a sokrétủ politikai újrarendeződés esetén elkerülhetetlen. A jogi pluralizmusnak a planetáris civil társadalom lesz a hordozója anélkül, hogy bármiféle egységesített jogrendszer megalkotásáról lenne szó. A világszerte alkalmazott jogi pluralizmus alapját társadalmi, konszenzuális mechanizmusok fogják alkotni, amint ezt Günther Taubner egy újabb munkájában világosan megfogalmazta, s így egy önmagát szabályozó jogalkotást képez a közjogi és magánjogi szereplök álláspontjának egyeztetése révén. Ebben az autonóm jogrendszerben a jogi aktusok és struktúrák kölcsönösen fognak egymásnak életet adni, és egymást áthatni. Nem lesznek alapvető szabályok, amelyek egy ún. meta-rendszernek felelnek meg - mint Kelsen elméletében a Grundnormen -, nem lesznek szankciók, mert a szimbolikus jogrend egy ismétlödö jogi aktusok folyamatának keretében minden egyes különleges eset lokális, regionális vagy globális jellegét fogja tükrözni. Így ,a jogi pluralizmust nem mint egymásnak ellentmondó és konfliktusban lévő jogszabályok sorát lehet meghatározni, hanem egy bizonyos társadalmi problémakört rendezö, sokrétü kommunikációs dialógus eredményét, melyek a társadalmi tevékenységet a tơrvényes-törvénytelen bináris kódja alapján kategorizálják" (Taubner 1997, 14). 


\section{Gazdaságpolitika és a gazdaság irányítảsa}

Miután az információs és kommunikációs technológiák egy új gazdasági szervezet létrehozása nélkül nem lehetnek kihasználhatók, két különösen fontos szervezeti változatot kell kiemelnünk: az első a térbeli restrukturálás általános gazdasági és vállalati vonalon egyaránt. Ez az új szervezési forma a munkaerő teljesen revideált térbeli elosztásán és az összes gazdasági tevékenység régiók közötti ujjászervezésén fog alapulni. E restrukturáció jó példáit képviselik a gazdasági tevékenységek általános szempontjából a kölcsönösen összefüggő munkaeröpiacok új adottságoknak megfelelö, tehát regionális kialakítása, lehetővé téve a megtakarítások skálájának lényeges megnövekedését. Míg a magángazdaság szempontjából bemutatható példa az a vállalati decentralizációs modell, amelyben az eddig gyárban végzett munkákat a vállalat központjától messze lakó bedolgozóknak is ki lehet adni. A struktúrák változásának ezeket a példáit egészíti ki az ún. hajlékony specializálódás programjává.

A hajlékony specializálódás lényegét, melynek eddigi legjobb példájaként Olaszország központi és északi vidékeit idézik, a következökben jellemezhetjlik:

1) Kis- és közép nagyságú vállalatok integrálódása a termelési folyamatok egyes részeinek egymással való megosztása, és ezen a módon egy flexibilis, folyamatos összeköttetésben álló termelési network létrejötte;

2) Az áruk minőségének és a lokális kultúrát kifejező designnak az elsődlegessége, mely a mesterségek újraélesztését és a munkaerőnek feladatok szerint való specializálását követeli meg;

3) Egy könnyen megváltoztatható és átszervezhetö, tehát rövid elöállitási folyamatokra beállított termelési program, amely nem a tömegtermelést célozza, hanem nagymértékben specializált termékek elöállítását, s így a helyi piacok rövid távú fluktuálását is követni tudja. Ez a követelmény teszi szükségessé a komplex - kiképzett munkásokból, technikusokból és specialistákból - álló munkacsoportok kialakítását;

4) Vállalatok közötti kooperációs szerződések megkötése és regionális ügynökségek létrehozása, melyeken keresztül a technológiai újitásokról és megváltozott piaci lehetőségekröl való információk azonnal szétszórhatók;

5) A társadalom tagjainak lokális és regionális nívón való együttmüködése, felhasználva a már meglévő network kapcsolatokat, melyeken keresztül biztosítani lehet a természeti környezet megvédésére vonatkozó erőfeszítésekbe vetett kölcsönös bizalmat.

Ebben a teljesen megváltozott gazdasági környezetben, ahol 'a kicsi a szép' schumpeteri elve lesz uralkodó, mindenkor a helyi és a régión belüli lakosság szükségleteinek kielégítése lesz elsődleges a jelen kompetitivitásra törő erőfeszítéseivel szemben, melyre az egyre nagyobb, de egyre kevésbé menedzselhető vállalatok megteremtésének lidércnyomásos álma készteti a vállalati vezetöket. A fentebb mondottakra egyébként a schumpeteri 'vezető szektorok' elmélete (Schumpeter 1939) is alkalmazható; ezek a szektorok az újításokat létrehozó vagy azonnal átvevő és a megfelelő kereslettel bíró árupiacokra specializálódó vállalatokból állnak, 
Segesváry Viktor : Globalizáció, hegemónia és a harmadik évezred politikai újjárendeződése; ezek egyes regionális vonatkozásai.

Tér és Társadalom 16. évf. 2002/4. 1-24. p.

TÉT XVI. évf. 2002 - 4

Globalizáció, hegemónia és ...

11

amelyek ezenkívül az energiafelhasználás és a szállitás olcsóbb lehetőségeit is ki tudják használni.

Monetáris szempontból nyilvánvalóan a regionális koordináló központoknak lesz a feladata a regionális pénzegység megfelelő mennyiségben való kibocsátásának biztosítása és garantálása annak a monetáris politikának az irányvonalai szerint, amelyet a részt vevö egységek közös szerve határoz meg. A világ egyes pénzegységeinek mai instabilitását a monetáris piacnak ez a feldarabolása sokban le fogja csökkenteni.

\section{A planetáris koordináció szükségessége}

A nem-centralizált politikai átrendezödés új világában is megmarad egyes problémakörökben a planetáris koordináció szükségessége. Ennek lehetöségét az információs és kommunikációs technológiák fogják biztosítani anélkül, hogy az államközi rendszer szinte elképzelhetetlenül bürokratizált szervezeteit újra kellene teremteni. Mivel a szükséges információk mindenkinek egyidejüleg rendelkezésére fognak állni, hosszú távú kérdésekben éppen úgy, mint a jelen sürgős problémáinak esetében, egy összehangolt akció kezdeményezése a 'virtuális' vitát lezáró határozatok eredmén yeképpen lesz lehetséges.

A két legfontosabb probléma, amelyeket planetáris nívón lehet csak kezelni, egyrészt a biztonság és a béke fenntartásának kérdése, másrészt pedig a természeti környezet és az ökológiai egyensúly megvédése az ipari civilizáció pusztító hatásaival szemben. E planetáris problémák széles körben ismertek, s mivel tárgyalásuk meszsze meghaladná ennek a tanulmánynak a kereteit, nem foglalkozunk velük.

\section{Az új politikai egységek együttmüködésének technológiai lehetöségei}

\section{Információ, információs társadalom és virtuális valóság}

Egy információnak csak akkor van értéke, ha van értelme és jelentösége, amit csak embercsoportok és egy kulturális környezet kölcsönözhetnek neki. A társadalom, az emberi történelem hajnala óta, mindig rendelkezett információkkal több, sokrétegü dimenzióban, melyek mindig emberek, vagy emberek és intézmények, emberek és a természeti környezet közötti kapcsolatokra vonatkoztak. Ami változott egyik kortól a másikig, az a rendelkezésre álló információknak tulajdonított értelem és annak társadalmi értéke volt, melyeket az adott kultúra határozott meg. A késöi modernitás korát viszont az jellemzi, hogy az információ önmagában jelent értéket, még akkor is ha nincs értelme, azért mert információval rendelkezni a haladással egyenlö.

Ma a digitális információ korában élünk, s társadalmunkat azért nevezzük információs társadalomnak, mert minden társadalmi tevékenység az információk és a kommunikáció folytonos és megszakíthatatlan közegében helyezkedik el. Bár az is tagadhatatlan, hogy az információs társadalomban sem elkerülhetetlen a tudatlan- 
Segesváry Viktor : Globalizáció, hegemónia és a harmadik évezred politikai újjárendeződése; ezek egyes regionális vonatkozásai.

Tér és Társadalom 16. évf. 2002/4. 1-24. p.

12 Segesváry Viktor

TÉT XVI. évf. 2002

ság, az információ hiánya, s még a digitális információ esetében is annak helytelen értelmezése. Az információs társadalom számára csak a jövő számít, a jelen vég nélküli folytatódásának formájában. Ennek értelmében az információs társadalom fogalma azt fejezi ki, hogy az új technológiák révén feltárult lehetőségek átformálják a társadalom életét, amint ezt Nicholas Negroponte kifejezte, ,a digitális világban olyan lehetőségek nyílnak fel, amelyek előzőleg megvalósíthatatlannak látszottak" (Negroponte 1995, 231). Ez a megfogalmazás feltételezi a múlttal való szakítást, egy történeti folyamatosság felszámolását. Az információs társadalomnak ezt a jellegét Manuel Castells fejezte ki a legtömörebben:

„Bár a technológia per se nem határozza meg a történelmi fejlődést és a társadalmi változásokat, a technológia birtoklása lehetôvé teszi a társadalmak számára önmegváltoztatásukat, $\mathrm{s}$ azt is, hogy a társadalmak, melyekben mindig konfliktuális folyamatok állnak egymással szemben, hogyan használják fel a gyakorlatban technológiai potenciáljukat" (Castells 1997, 7).

Az információs társadalom fogalma szorosan összefủződik a virtuális valóság elképzelésével, mert lehetségessé teszi képzeletbeli helyzetek összjátékát, s ezek végnélküli újrateremtését az ún. cybertérben. A virtuális valóság különbözik az utópiától, mely a világ egy ideálisnak tartott állapotát írja le a jelen szomorú állapotával szemben. Mind a virtuális valóság, mind az utópia a jövőre vonatkozik, de míg az utópia egy olyan világot ír le, amelyben az általa meghatározott értékekre való elkötelezettség elengedhetetlen, a virtuális valóság teljesen nyitott a jövövel szemben, és megengedi a jövőben létrehozott állapotok állandó újraformálását. A virtuális valóság nyitottságát az teszi lehetövé, hogy benne a tér és az idő fogalmai teljesen relatívak és a terükben vagy temporális folyamataikban való mozgás független az „embervilágokban” uralkodó tér és idő koncepcióitól.

\section{Információs társadalom és közösségi network hálózatok}

Az emberi közösségek egy közös világnézeten alapulnak, amely nemcsak a közösség hagyományaiban és történelmi tapasztalataiban, hanem elsösorban nyelvükben gyökerezik, s világképüket meghatározza. Ezért fontos a helynek, a fizikai és kulturális összefüggőségnek, és a nem messze terjedỏ térbeli világnak a kihangsúlyozása. John Dewey, az amerikai pragmatizmus legnagyobb alakja, már régen elismerte, hogy a közösségek kialakulását kizárólag a kommunikáció tette lehetővé - „konszenzus nem lehetséges kommunikáció nélkül” (Dewey 1916, 5-6) -, ha a kommunikáció legegyszerübb meghatározását fogadjuk el, vagyis azt, hogy a kommunikáció nem más, mint eszméknek, gondolatoknak és események hírének térben és időben való továbbadása. A kommunikáció történhet egyrészt az egyre fejlettebb technológiák révén - például üzenetek továbbítása nagy távolságokon keresztül -, de lehetséges másrészt a hagyományos, rituális módon is, amikor nem információk továbbadását szolgálja, hanem a közösség világnézetének szimbolikus megjelenítését és megerősítését, ahogy ezt már Émile Durkheim leîrta $A$ vallásos élet elementáris formái címủ korszakalkotó müvében. A kommunikációnak ez a kettős értelme 
Segesváry Viktor : Globalizáció, hegemónia és a harmadik évezred politikai újjárendeződése; ezek egyes regionális vonatkozásai.

Tér és Társadalom 16. évf. 2002/4. 1-24. p.

TÉT XVI. évf. 2002 - 4

Globalizáció, hegemónia és ...

13

fontos az intézményesített politikai networkszerü közösségek esetében is, mert az információs és kommunikációs technológiák nemcsak az átadás és szétszórás feladatait viszik végbe, de a rituális és szimbolikus funkciót is betöltik, ha nem is közösség-teremtők, de mindenképpen közösség-fenntartók.

Vitatott kérdés, hogy miképpen jön létre egy közös célokat elérni óhajtó, network részét képező komponensek együttese. A legtöbben azt állítják, hogy ezek a network-közösségek a komputer által közvetített kommunikáción [computermediated communication - $\mathrm{CMC}$ ] keresztül, tehát az elektronikus kapcsolatnak köszönhetöen jönnek létre, míg más vélemények szerint a cybertérben létrejött közösségek nem újak, hanem a valóságban már meglévő közösségeket tükrözik. Itt idéznünk kell Steven Jonest, aki világosan állást foglalt a második változat mellett:

„A valóság on-line társadalmi konstrukciója nem a komputer által közvetített kommunikációk networkjén keresztül jön létre, hanem magában a networkben testesuil meg. Sokkal könnyebb megérteni azokat a fizikai kapcsolatokat [hardwire], amelyek a társadalmi együttmüködést szolgálják, mint az azokból megszülető szimbolikus kapcsolatokat ... Senki nem tudja megmagyarázni, hogy mi voltaképpen a komputereknek, mint eszközöknek a szerepe e kapcsolatok és közösségek megteremtésében ... Egy kapcsolat nem feltétlenül vezet egy közösség megteremtéséhez, sőt nem feltétlenül vezet sem információk kicseréléséhez, sem értelmezések átadásához ..." (Jones 1995, 5-7).

Végeredményben a médiák által létrehozott társadalmi struktúrák nem teremtenek egy közösen átélt valóságot. Egyes eseménynek a tömegmédiákon keresztül való látása minden egyes nézőben teljesen más élményt kelt, mert minden néző magával hozza az esemény értékelésének elemeit nem a virtuális, hanem az igazi valóság világából. A komputeren keresztül való kapcsolatteremtés azért lehetséges, mert a komputer mint média egyszerre jelenti a kontextust, amelyben a kapcsolatok létrejönnek, és azt az eszközt, amelyen keresztül a cybertér megnyílik elöttünk. Ezzel egy időben a komputerek elhatárolják egymástól a network hálózat résztvevőit, és hierarchiákat teremtenek azáltal, hogy felerösítik az identitásokat és kihangsúlyozzák a networkben résztvevök közötti különbségeket, hiszen a szimbolikus és rituális folyamatok magukkal hozzák a nem-virtuális világból származó meggyőződéseket és elképzeléseket. A komputerek által közvetített kommunikáció sokkal inkább személytelen, mint az írott szöveg, s így az Interneten keresztül teremtett kapcsolat nem feltétlenül kommunikáció. A cybertérben létrehozott kapcsolatoknak ez a vonása határozza meg a politikai-intézményes közösségek komplex voltát, s a komputeren keresztüli kommunikációban egyes csoportok pontosan ezért mindig a való világban már előzőleg létező közösségekhez tartoznak.

A jövő általunk javasolt politikai újjárendeződése, mely nem területi alapokon fog nyugodni, hanem kulturális közösségeken, a mai államoknál kisebb egységeket fog magában foglalni. Ezek esetében, de különösképpen akkor, ha ezeknek az egységeknek a részei nem összefüggő településeket alkotnak, az információknak a cybertéren keresztüli továbbadása és szétosztása a politikai tevékenység elmaradhatatlan feltétele lesz. Ebben a perspektívában a mai állami berendezkedésnek, például 
a reprezentatív demokráciának vagy a hatalom hármas megosztásának, nagyfokú átalakuláson kell keresztül mennie. Így a reprezentativitás elve nem fog eltünni, hiszen még az önkormányzó lakossági intézményeken belül sem lehet minden kérdést, kivéve a legfontosabbakat, szavazások formájában eldönteni, s így nem lesz elkerülhető a hatalom bizonyos fokú delegálása. Viszont valószínủ, hogy az elektronikus szavazási módszer szükségtelenné teszi majd a törvényhozó szervek létét, hiszen a törvényhozást az amúgy is kisebb egységek lakossága a maga egészében fogja elvégezni. Ebből a szempontból a legfontosabb az lesz, hogy a többség diktatúrájának elkerülésére megfelelő garanciák biztosítsák a kisebbségi szavazók érdekeinek és jogainak tiszteletben tartását.

\section{Technológiák és a szükséges infrastruktúra}

\section{Infrastrukturális adottságok és virtuális közéleti szférák}

Az Internet és a World Wide Web, mint autonóm és sokrétegü funkcióra alkalmas politikai-közéleti terek, biztosítják a közösségeken belüli és a közösségek közötti egyre számosabb network hálózatok lehetőségét. Ha a megfelelő infrastruktúra még nem is létezik minden esetben, biztosak lehetünk abban, hogy ha egyszer egy új technológiai szükséglet jelentkezik, akkor ezt a specialisták hamar ki fogják elégíteni. A legfontosabb szempont az, hogy a technológiai fejlődés a kollektivitás érdekeit szolgálja.

Melyek a politikai-közéleti cybertér alapvető jellemzői? Anthony Wilhelm öt ilyen jellemzöt sorol fel:

- Az elsö, topografikus, meghatározását adja annak a térnek, amelyben a résztvevők vitázhatnak, információikat és terveiket kicserélik;

- A második, tárgyszerü, összefoglalja azokat a kérdéseket, amelyeket a résztvevők dialógusukban megtárgyalhatnak;

- A harmadik, teljesség, mely azt a demokratikus elvet tükrözi, hogy bárki részt vehet a topografikusan meghatározott térben folytatott politikai megbeszélésekben és vitákban;

- A negyedik, design, mely nemcsak a demokratikus szavazási eljárásokat teszi lehetővé, hanem különféle, más komponensek beiktatását is, például kritikai véleménycseréket;

- Az ötödik, tanácskozás, mely végeredményben a demokratikus politikai élet lényegét jelenti, hiszen semmiféle politikai-intézményes elrendezödés nem hozhatja meg az elvárt eredményeket, ha a fent említett négy jelleg, de elsősorban a design és a technológiai infrastruktúra felépítése nem biztosítják, és nem könnyítik meg a politikai kérdések megvitatását (Wilhelm 1999, 155-159).

Az új politikai egységek esetében az információs és kommunikációs technológiák által kialakított környezet változó lesz nagyságuknak, részeik összefüggésének vagy egymástól való távolságának, valamint az uralkodó gazdasági és társadalmi feltételeknek megfelelően. De ezek a változó környezetek nem befolyásolják sem a szer- 
Segesváry Viktor : Globalizáció, hegemónia és a harmadik évezred politikai újjárendeződése; ezek egyes regionális vonatkozásai.

Tér és Társadalom 16. évf. 2002/4. 1-24. p.

vezeti felépítés által létrehozott sokrétegú funkciókat vagy a technológiai hálózatot és annak használati feltételeit, sem a tartalom helyességét és a továbbítás megfelelő voltát.

A szervezési-infrastrukturális alapokat elsösorban a pluralizmus követelményének kielégítése fogja jellemezni. Ebben az értelemben a pluralizmus a médiák pluralizmusát és az információ tartalmának sokrétüségét jelenti. Az információk vagy általános jellegủek lesznek, vagy a közéleti kérdések egyes különleges szempontjait érvényesítik, mindenekelőtt helyet adva a döntésre váró politikai és intézményes problémáknak. A legtöbb gyakorlati, adminisztrációs probléma - költségvetés, adópolitika, a fizikai infrastruktúrára vonatkozó programok, mint hidak, csatornák és utak építése, vagy kórházak létrehozása a helyi közösségek szükségleteinek kielégítésére - ebbe a kategóriába fog esni, míg a regionális biztonság kérdése, a környezetvédelem vagy az egyes egységeket összekötő fizikai infrastruktúra létrehozása, az egységeket koordináló szervek hatáskörébe kerül.

A politikai közélet cyberterének tartalmi pluralizmusa azt fejezi ki, hogy az információk magukba fogják foglalni a helyi, szubregionális és regionális partikularizmusok és kulturális identitások kifejezését, ugyanakkor helyet biztosítva a lokális kontextusokhoz kapcsolódó ellentétes véleményeknek és ideológiai vagy más különbségeknek. Featherstone szavaival, a jövö pluralizmusa „egy olyan egységes keretet fog alkotni, melyben a különbözöségek minden további nélkül megférnek egymással" (Featherstone 1990, 2).

A szerkezeti pluralizmus következményeképpen, egyrészt a résztvevök száma hatalmasan meg fog növekedni, másrészt az egyes egységek és szférák közötti átfedés [spillover] nagy mértékủ lesz, például a technológiailag fejlettebb és fejletlenebb részek között. Ezt az is lehetövé fogja tenni, hogy az Internet és World Wide Web kettősége meg fog maradni, de ezeket ki fogják egészíteni eddig még nem ismert online infrastruktúrák is. Ez azt jelenti, hogy az információkat és kommunikációkat a magántulajdonban lévő infrastruktúrák fogják közvetíteni; viszont az infrastruktúrát irányító és szabályozó szervekben a közösségek képviselöinek kezében lesz a kontroll. A piaci verseny elvét azonban ezek a szervek sem törölhetik el éppen azért, hogy ne lehessenek a bürokratikus kísértéseknek kitéve.

\section{Információs és kommunikációs rendszerek}

Ezeket a rendszereket egyrészt a bennük használt közvetítö elem - a leírt vagy mondott szó, grafikák és más kisegítő ábrázolások használata -, másrészt a részt vevö csoportok szerkezete és nagyságrendje határozza meg. Az elektronikus kommunikációban a leírt szó lehetővé teszi a kommunikációk hosszát és gyakoriságát kontrollálni, s a komputer az egyetlen közvetítő berendezés, amely memóriájában mindent meg tud örizni, ami a kommunikációs folyamatban kifejezésre jutott. Az ún. hypertextek esetében a komputerek nemcsak strukturálják, hanem integrálják is a programokat és folyamatokat, $s$ ezen kívül más szükséges funkciókat is ellátnak, mint pl. a résztvevök számára szükséges anyagok összegyüjtése, rendbe szedése, 
Tér és Társadalom 16. évf. 2002/4. 1-24. p.

kiszűrése, formába öntése, a feedback közléseknek a megfelelő csatornába való irányítása, vagy a kommunikációs elemeknek a memóriában való megkeresése.

A fenti tulajdonságokkal rendelkező különféle információs rendszerek között megemlítjük azokat, amelyek a politikai kommunikáció szempontjából a leghasználhatóbbak lesznek (minden ide vonatkozó információ forrása Lenk 1999):

Elöször, a témák és problémák kategóriáin alapuló rendszerek (IBIS - issue-based information systems). Mivel nem minden információ áll rendelkezésre egy politikai döntéseket célzó eszmecsere és vita kezdetekor, e rendszerek az információk kategóriába való osztásával és azok egy egészbe való betagolásán keresztül biztosítják, hogy a világosan megfogalmazott témák minden résztvevőhöz eljussanak, s így a kérdések feltevése és a megoldások megtalálása könnyebbé váljon. Minden résztvevő hozzászólása kérdések, válaszok és érvek kategóriáiba kerülhet, s a végeredmény az, hogy egy specifikusan a problémák irányába orientált network jön létre.

Másodszor, a döntéseket megkönnyítő rendszerek (DDS - decision support systems), melyek egy racionális, probabilista és formális módszerrel dolgoznak, néha vizuális kifejezéseket is felhasználva. Bármilyen elméletre vagy feltételezésre történik hivatkozás, ezeket a rendszer analizálja, értékeli és következményeikkel együtt bocsátja a résztvevők használatára. Az egyes variációknak a végső döntésre való esetleges befolyását is jelezve a software ezeket kiértékeli, $s$ a megbeszélés és vita eredményeit újra átvilágítja.

Harmadszor, a csoportdöntéseket megkönnyítő rendszerek (GDSS - group decision support systems) kimondottan egy csoport által meghozandó döntésekre specializálódnak, mint pl. egy ügyrend elkészítése, brainstorming, kommentárok megírása, szavazás vagy a viták lefolyásának dokumentálása, hiszen az ilyen csoportok munkájának lényege, hogy megfelelöen struktúráltak legyenek technikai és tartalmi szempontból.

Az elözőekben említettekkel szemben vannak specifikus célok megvalósítására létrehozott network típusok is. Ezek között találhatjuk a komputer által lehetővé tett kooperatív együttmüködésre ( $\mathrm{CSCW}$ - computer-supported cooperative work) vonatkozókat, melyek nemcsak strukturálják a vitákat, hanem még azt is meghatározzák, hogy a résztvevők közül kinek mennyi témát lehet felhozni a vitában, vagy kommentálni a mások által megjelölt problémákat. A közösségeket informáló szervezeti network típusok fókuszában (CIN - community information network) helyi körülmények és az azokban élők állnak, így ezek a szélesebb körü közösségi együttmúködés elómozdítását szolgálják. Sikerük azt mutatja, hogy csak akkor funkcionálnak jól, ha információik helyi forrásokból erednek, vagyis ha széles körü, decentralizált és elsődleges kézböl való információkra támaszkodnak. Legjobb példái az ilyen network típusoknak a The Democracy Network (DNet) Kaliforniában (Docter-Hutton 1999), valamint The Institute of Global Communications (IGC - Friedland 1996), mely nem földrajzilag, hanem szektorális szempontból specializált - mezögazdasági kérdésekre. Végül egy európai példa, a Network Pericles Görögországban (Tsagarousianou-Tambini-Brian 1998, 43-52). Ez utóbbi érdekes vonása, hogy az állampolgárok elidegenedését és a demokratikus politikai rend- 
Segesváry Viktor : Globalizáció, hegemónia és a harmadik évezred politikai újjárendeződése; ezek egyes regionális vonatkozásai.

Tér és Társadalom 16. évf. 2002/4. 1-24. p.

TÉT XVI. évf. 2002

szerből való kiábrándulását akarja megállítani, felelevenítve a klasszikus athéni demokrácia emlékét, $\mathrm{s}$ bátorítva a polgárokat a politikai életben való aktív részvételre és ezen keresztül az önkormányzatok megerösítésére.

Végül szólnunk kell röviden a cybertér pluralista müködésének jogi feltételeiről. A cybertér mủködését egyrészt a privát múködtetők önfegyelme garantálja, másrészt a benne részt vevő közösségek által létrehozott szerveknek kell felette szigorú felügyeletet gyakorolniuk. Erre elsősorban szükség van az Internet, a World Wide Web és általában a tömegmédiák ún. tartalmi relativitása miatt. Minden kereskedelmi vállalkozásban a tulajdonosok és a müködtetők anyagi, esetleg ideológiai érdekei határozzák meg a tartalom milyenségét és minőségét, míg a politikai kommunikációban a tartalmat a közösségnek kell meghatároznia, s a tartalom relativizálása elfogadhatatlannak minősül a közérdek szempontjából. Ebben az értelemben az információk tartalma térbeli, tehát horizontális, és időbeli-történelmi, vagyis vertikális jelleget mutat fel ellentétben a mai információs folyamatok nagy részének térbelileg absztrakt és időbelileg ahisztorikus jellegével. A globális információs trendeket végeredményben egyes érdekek túlsúlya és ezért egy centralizált orientáció jellemzi, elsősorban az események minősítésében és magyarázatában, valamint a nyilvănos vita kontextusának meghatározásában.

A cybertér szabályozása nemcsak a helyi és regionális kultúrák szerepére vonatkozhat. A globális és lokális trendek ki fogják egymást egészíteni a politikai közösségek network hálózataiban azon keresztül, hogy a helyhez kötött nézetek és szándékok globalizálódnak, viszont a globális perspektívák és szempontok beleágyazódnak a kommunikációs kontextusba. A természetes többnyelvűség ehhez nagy mértékben hozzá fog járulni, ami persze azt is szükségessé teszi majd, hogy globálisan homogén és interaktív komputer nyelvek álljanak rendelkezésre, mint pl. a Java.

Mindez aláhúzza a cybertér szabályozásának szükségességét az információs és kommunikációs technológiák helyi, regionális és globális követelményeivel egybehangzóan. A politikai kommunikáció terén tehát nem lehet szó egy network szuverenitásáról (Reidenberg 1997), mert a network hálózatok szuverenitását csak az érdekelt politikai közösségek gyakorolhatják. Az alkalmazott technológiára vonatkozó döntések, azok normái és az egyes softwarek designja, kizárólag politikai döntéseken alapulhatnak, melyek változtatásokat követelhetnek meg a designban éppen úgy, mint az infrastruktúra felépítésében. Ilyen változtatások lehetnek, pl. olyan algoritmusok beépítése, amelyek egyes kommunikációk nyilvánosságának lecsökkentését, vagy az új kommunikációs folyamatok kontrolljához szükséges eszközök bevonását célozzák.

\section{Excursus az állampolgársági státusról}

Az állampolgársági státust a modern állam teljhatalma követelte meg, mely minden más lojalitást, mint a hozzá való hűséget, elpusztítani igyekezett polgárai öntudatából. Az alattvalóknak nem lehetett máshoz lojálisnak lenni, pl. etnikai, vallási vagy bármely más alapon létrejövő közösségükhöz, mint a mindenható államhoz. 
Ez tulajdonképpen a civil társadalom gyökereinek elpusztítását jelentette, s ez a tény ma egyre inkább nyilvánvalóvá vált a demokratikus társadalmakban. Egy állampolgár tehát egy absztrakt individuum, s ezeket az atomszerü egyéneket integrálja az állam saját kollektivitásába azon keresztül, hogy egy állampolgárnak nem lehet más identitása, mint az állampolgári identitás - amit Habermas ,alkotmányos patriotizmusnak" nevez. Minden ország állampolgára, aki rendelkezik a megfelelö adottságokkal és képességekkel, gyakorolhatja demokratikus jogait időközi választások alkalmával, s ennek ellenértékeként fizetnie kell adót, szolgálnia kell a hadseregben, engedelmeskednie kell a törvényeknek, s lelkesednie kell az állam vezetői által meghatározott célokért. Az a tény, hogy valaki automatikusan megkapja az állampolgárságot azt is jelenti, hogy születésénél fogva rendelkezik a törvényekben meghatározott adottságokkal és képességekkel állampolgári kötelességeinek kielégítésére és jogainak gyakorlására, s ha bármely területen nem felel meg a követelményeknek az nem az egyes állampolgárok hibája, hanem a társadalmi és politikai körülményeknek és az intézmények gyengeségének köszönhetỏ.

\section{Excursus a planetáris koordináció szükségességéröl}

\section{A biztonság és béke fenntartása}

Mára már mindenki számára nyilvánvaló lett, hogy az Egyesült Nemzetek Szervezete képtelen legfóbb feladatát, a nemzetközi biztonság fenntartását Kartájának értelmében garantálni. Amikor a világ két politikai táborra szakadt, a biztonság záloga a két tábor közötti hatalmi egyensúly volt, ami mindkettőt arra kényszerítette, hogy ne forduljon az erőszak alkalmazásához a másikkal szemben. Amikor a Szovjetunió köré tömörült Varsói Szerződés megszủnt (meg kell jegyezni, hogy nem a Nyugat bármiféle erőfeszítésének, hanem belső felbomlásának eredményeképpen), a bipoláris világ átalakult egyetlen katonai és technológiai nagyhatalom világává, az Amerikai Egyesült Államok hegemóniája alatt. A nemzetközi biztonság és a béke fenntartása ma ezért két perspektívában jelentkezik:

Elöször, a nukleáris háború veszélye mára sem tủnt el teljesen, felelötlen politikusok és ideológusok elöreláthatatlan tevékenysége miatt. Így egy nukleáris konfrontációt robbanthatnak ki közepes nagyságú, de nukleáris fegyverekkel rendelkező hatalmak, mint Pakisztán vagy India, melyek veszélyeztetve érezhetik magukat régi ellenségeiktöl, vagy olyan hatalmak, mint Kína, amely egy nagyhatalmi pozíciót akar elnyerni.

Másodszor lokális konfliktusok, melyeket etnikai, gazdasági vagy civilizációs ellentétek válthatnak ki kisebb vagy közepes nagyságú nemzetállamok között, különösképpen Afrikában, a Közel-Keleten vagy a Balkánon. Ezeknek a konfliktusoknak az elterjedése egy teljesen természetes jelenség a kettéosztott világ eltủnése után, melyben a két tábor közötti ellentét halasztotta el ezeknek a lokális konfliktusoknak a kitörését. Ezeket a lokális konfliktusokat semmiképpen nem tudják meg- 
Segesváry Viktor : Globalizáció, hegemónia és a harmadik évezred politikai újjárendeződése; ezek egyes regionális vonatkozásai.

Tér és Társadalom 16. évf. 2002/4. 1-24. p.

TÉT XVI. évf. 2002 — 4

Globalizáció, hegemónia és ...

19

szüntetni sem az Egyesült Nemzetek, sem az Egyesült Államok által vezetett államközi direktórium beavatkozásai, két ok miatt:

1) A nemzetközi közösség tagjainak, de elsösorban az ezt irányító Egyesült Államoknak a döntő fellépést elkerülő taktikája, mert egy demokráciában katonák életének elvesztése ugyanakkor szavazatok elvesztését is jelenti;

2) Ugyanezeknek az államoknak a high-tech fegyverek alkalmazása (sokszor pusztító beavatkozása egy helyi konfliktusba, mint pl. a koszovói válságba, rosszul felfegyverezett katonai erők ellen, vagy a civil népesség bombázásával) csak fokozza az antagonizmusokat és a bosszú tüzét, mint pl. az izraeli polgárháborúban.

A tanulmányban javasolt politikai újjárendeződés egyik fö célja az lenne, hogy ezeknek a helyi konfliktusoknak az okait eltüntesse, mert ezek a konfliktusok egyre gyakrabban fogják a biztonságot és a béke fenntartását veszélyeztetni az elkövetkezö évek folyamán. Az etnikai, nemzeti és kulturális különbségek lekicsinylése a demokrácia és piaci verseny nyugati protagonistái részéről, vagy a különféle 'embervilágok' közötti különbségek tagadása a világ-civilizáció hirdetői által, soha sem fogják meggyőzni a népeket annak szükségességéről, hogy hátat fordítsanak történelmi és kulturális hagyományaiknak a diplomáciai beavatkozások, bombázás vagy pusztítás hatása alatt.

A világbiztonság kérdései, $s$ különösképpen a lokális konfliktusok továbbra is a planetáris politika fontos problémái maradnak, mert ezek nemcsak objektív tényeknek felelnek meg, hanem azoktól az emberektől is függenek, akik kommunikálnak, de kommunikációjuk tartalmában nem lehet megbízni (el kell felejteni azokat az anderseni meséket, amelyek az emberek velük született jóságáról szólnak). Bár ezen a téren semmit nem lehet elöre látni és megjósolni, az valószínünek tủnik, hogy a kisebb politikai egységek esetében, amelyek legnagyobb része nem rendelkezik számottevő katonai erőkkel és a szükséges anyagi forrásokkal, a konfliktusok dimenziója és száma csökkenni fog. Elsösorban arra kell azonban számítani, hogy a nemzetállamok felszámolása a hatalmi ellentétek lecsökkenéséhez fog vezetni, mert a múltban pontosan ezek a hatalmi ellentétek tüzelték az államok közötti pusztító konfrontációkat, veszélyeztetve a világ biztonságát.

\section{A természeti környezet és az ökoszisztéma védelme}

A természeti környezet pusztulásának megakadályozását nem lehet helyi és regionális kontextusokban hatékonyan megoldani. Ezen a téren a technológiai fejlödés inkább súlyosbítja a helyzetet, mintsem könnyítené a problémák orvoslását, mert abból ered, hogy megszédülve a tudomány eredményei által, az emberek azt hiszik, hogy az ember képes a természetet átformálni. Az ökológiai rendszer teljes összeomlása annak következménye, hogy a planetáris egyensúly a természeti világ és az emberek világa között teljesen felborult az 'embervilágok' javára. Túl sok ember él földünkön ennek anyagi forrásaival összehasonlítva, s ezt egyszerủen ki lehet számolni, ha megszorozzuk az emberek számával a fejenkénti természeti források 
fogyasztását. Úgy is lehet mondani, hogy a természeti világ egy zárt, míg az emberek világa egy nyitott rendszert képez. Egy zárt rendszerben, mint a természeti világ, a különféle anyagi források tömege se nem nö, se nem fogy, s az energia felhasználásának folyamata nem hoz magával minőségi változásokat; ugyanakkor az emberi világ nyitott rendszerében az anyagi eröforrások felhasználása a végtelenségig fokozódhat, mert a tudományok és technológiák eredményeinek folytán a természet kihasználásának elvben nincs határa. A konklúzió tehát nem lehet más, minthogy a két egymással szemben álló rendszer viszonya a természet anyagi forrásainak teljes eltủnéséhez vezet, mert a természeti világ önmagát újrateremtő hatalmának is vannak határai.

\section{Excursus az analóg és digitális információs rendszerekröl}

Anthony Wilden, az információs társadalom egyik korai protagonistája fejezte világosan ki az analóg és digitális információs rendszerek közötti különbséget, amikor azt írta, hogy ,a digitális mód az információt küldő és a címzett közötti viszonyon kívül helyezkedik el, s a kettö közötti kapesolatot közvetíti; míg az analóg mód a kettő közötti kapcsolatnak felel meg" (Wilden 1972, 173). Az analóg mćdban az értékelések nagy fontossággal rendelkeznek, de a digitális kommunikációs mód alkalmazásának esetében nincs jelentőségük, mert az információ kívül esik az üzenetnek, az információnak a keretein. Ennek következtében az első esetben az üzenet és értelmezése kétséges, de a második, digitális módban, bár önkényesen lefektetett kombinációkon alapszik, s használata elkerülhetetlenül korlátozott, mondanivalója pontosan megfogalmazott, és nem hord magában semmiféle kétértelmüséget. Ezért Wilden konklúziója az, hogy ,az analóg módban átadott információnak egy meghatározott értelme van, míg a digitális módban kifejezett információ fontossága jelentőségén múlik" (Wilden 1972, 163).

\section{Zárószó}

A területileg meghatározott nemzetállam válsága és hanyatlása ma már egyre szélesebb körökben elismert tény. Az emberek egyre jobban kötődnek kultúrájukhoz, a kultúra által kondicionált társadalmi léthez és szokásokhoz, mintsem az államuk területi identitásához. Az egyének és közösségek identitásának fontosságát egyre jobban kihangsúlyozza a globális és a lokális, a nemzetállami jelleg és a kozmopolita törekvések dialektikája.

A globalizáció minden látszat ellenére is alapjaiban támadja meg a nemzetállam létét pontosan azért, mert felnyitja a világot az egyének szemei előtt, $s$ megmutatja annak tarkaságát, hallatlan emberi és kulturális gazdagságát mindenki számára. Ennek ugyanúgy bizonyítéka a transznacionális mozgalmak jelensége, elsősorban a szegényebb országokból a gazdagabb országok felé, mint a médiák hallatlan befolyása az emberi élet minden szférájában. 
Segesváry Viktor : Globalizáció, hegemónia és a harmadik évezred politikai újjárendeződése; ezek egyes regionális vonatkozásai.

Tér és Társadalom 16. évf. 2002/4. 1-24. p.

Végeredményben a globalizáció nagyban hozzájárult az identitások, az etnikai, nemzeti és kulturális öntudatok megerösítéséhez, $\mathrm{s}$ a globális kor egyik legjellemzőbb vonása a kisebbségek jogainak követelése minden eddigi történelmi tapasztalatot meghaladó mértékben. Az önrendelkezés követelménye valósággal széttöri, szétrepeszti a nemzetállami intézmények jogi és politikai kereteit.

A globalizáció másik arca - ahogy a civilizációk dialógusát nevezhetnénk - szintén a globális és a lokális dialektikájának következménye, s a kulturális és civilizációs pluralizmus lényegét képezi, s így az önrendelkezés morális és demokratikus követelményével egymást felerősítik.

A nemzetállami politikai intézmények hanyatlásának másik meghatározó tényezője a demokratikus politikai rendszerek válsága. A rousseau-i társadalmi szerződés elmélete ma már elavultnak tünik az egyre nagyobb népességú államok keretében, ahol a lakosság egyes csoportjai különböző identitásokat képviselnek, s a demokratikus rendszer normális funkcionálása szinte lehetetlenné válik, mert a kisebbségi csoportok még egy számszerü többséggel és annak diktatúrájával szemben is követelik jogaikat a demokratikus önrendelkezés nevében.

Az Egyesült Nemzetek intézményének megfelelően létrehozott világállamot, a kialakulóban lévőnek hitt világkultứrát és világ-civilizációt csak azok akarják megvalósítani, akik a nyugati civilizáció egész világra való kiterjedését, a világ népei életének kulturális, társadalmi és politikai uniformizálását szưkségesnek tartják, s ezt a kozmopolitizmus révén akarják előmozdítani. A legutóbbi fél évszázad eseményei, az egyre elterjedtebbé váló fundamentalizmusok nyilvánvalóvá tették az ilyen világállami álmoknak és kozmopolita vagy hegemonikus reményeknek az irreális voltát. Sajnos, e két ideológia ámokfutóinak harca mindenütt a civil népesség nagy tömegeinek szenvedését hozza magával, bár a különféle társadalomban élők éppúgy elfogadják a globális világ perspektíváját, mint amennyire ragaszkodnak lokális térségük kultúrájához, hagyományaihoz és életmódjához.

Mindezek a meggondolások arra vezetnek - még ha sokak szemében ez utópikusnak tủnik is -, hogy a harmadik évezred politikai újjárendeződésének egyetlen lehetséges, a globális és lokális követelményeinek egyszerre megfelelő formáját kell kidolgozni. Ez sokkal nagyobb számú, de jóval kevesebb lakossággal bíró, és nem területileg meghatározott, nem centralizált demokratikus egységek és intézmények megalkotásában jöhetne létre. Ezeknek az egységeknek konstitutív elemei különféle közösségek lesznek, melyek regionális és szub-regionális keretekben kapcsolódnak össze. E sokrétủ térségekben elhelyezkedő intézményeknek társadalmi, gazdasági és politikai tevékenységét regionális és szub-regionális koordináló központok hangolhatják össze anélkül, hogy bürokratikus hatalmat gyakorolnának a regionális térségben együttműködő egységek felett.

Annak, hogy ez az utópikusnak tetsző politikai újjárendeződés megvalósulhasson, az élenjáró információs és kommunikációs technológiák adják meg a lehetőségét. $\mathrm{E}$ technológiák egyrészt biztosítják a kisebb politikai, esetleg nem összefüggő területeket is magában foglaló egységeken belüli demokratikus választások megfelelö lefolyását, és az állandó, két irányú konzultáció lehetőségét a lakosság és az irányító 
szervek között - ennek ma már egyre több példáját láthatjuk. Másrészt ezek a technológiák megteremthetnék a regionális vagy szub-regionális térben fekvö kisebb egységek szociális, gazdasági és politikai együttmúködését garantáló network kapcsolatokat, elsősorban a régiók közötti biztonság fenntartását és az emberiség ökológiai környezetének megvédését. Mindez azonban szükségessé teszi, hogy az információs és kommunikációs network kapcsolatok egy megfelelö jogi szabályozás keretében müködjenek, s így a közösségek kontrollja a regionális és szub-regionális koordináló központok felett ne jelentsen problémát.

$\mathrm{Az}$ államközi viszonyok mai rendezetlensége, egy hegemonikus kapcsolatrendszer kialakulása, az egyre több lokális konfliktus, melyek legnagyobb részt a kisebbségek önrendelkezési jogainak el nem ismeréséböl erednek, a modernizációs eröfeszítéseknek a civilizációs különbségekböl és a nemzetállami politikai intézmények elégtelenségéböl fakadó sikertelensége a nem-nyugati világ országaiban, elkerülhetetlenné teszik tehát a jövő politikai újjárendeződésének merész és a múlt szokásaival szakító elképzelését.

\section{Irodalom}

Badie, B. (1995) La fin des territoires: Essai sur le désordre international et sur l'utilité sociale du respect. Fayard, Paris.

Brohman, J. (1995) Economism and Critical Silences in Development Studies: A Theoretical Critique of Neoliberalism. - The Third World Quarterly. Vol. 16. 297-318. o.

Bull, H. (1995) The Anarchical Society: A Study of Order in World Politics. Columbia Press, New York.

Camillieri, J.-Falk, J. (1992) The End of Sovereignty? The Politics of a Shrinking and Fragmented World. Hants, Edward Elgar, Aldershot.

Castells, M. (1997) The Information Age: Economy, Society and Culture. The Rise of the Network Society. Blackwell, Oxford.

Coombes, D.-Rees, N.-Stapleton, J. (1991) Territory and Function in Economic Development. Administration. Vol. 39. 107-132. o.

Cox, R. (2000) Thinking About Civilization, - Review of International Studie. December. 217-234. o.

Dewey, J. (1916) Democracy and Education: An Introduction to the Philosophy of Education. Macmillan, New York.

Docter, S.-Dutton, W.H. (1999) The Social Shaping of The Democracy Network (DNet). - Hague, B.N.Loader, B.D. (eds.) Digital Democracy: Discourse and Decision-Making in the Information Age. Routledge, London. 222-243. o.

Elkins, D.J. (1995) Beyond Sovereignty: Territorial and Political Economy in the Twenty-First Century. University of Toronto Press, Toronto.

Featherstone, M. (ed.) (1990) Global Culture; Nationalism, Globalization and Modernity. SAGE Publications, London.

Fernandez, A.E.-Mommen, J.-Mommen, A. (1998) Regionalization and Globalization in the Modern World Economy: Perspectives on the Third World and Transitional Economies. Routledge, London.

Friedland, L. (1996) A. Electronic Democracy and the New Citizenship. - Media, Culture, and Society. Vol. 18. 185-212. o.

Geertz, C. (1963) The Integrative Revolution: Primordial Sentiments and Civil Politics in the New States. - Clifford, G. (ed.) Old Societies and New States: The Quest for Modernity in Asia and Africa. Free Press, New York. 109-113. o.

Golden, J.R. (1994) Economics and National Strategy in the Information Age: Global Networks, Technology Policy, and Cooperative Competition. Westport. Praeger, Connecticut.

Habermas, J. (1975) Legitimation Crisis. Beacon Press, Boston.

Hagen, J. von, (ed.) (1998) Territoriality in the Globalizing Society: One Place or None? Springer, Berlin.

Hakli, J. (1994) Territoriality and the Rise of the Modern State, - Fennia. Vol. 172. 1-82. o. 
Segesváry Viktor : Globalizáció, hegemónia és a harmadik évezred politikai újjárendeződése; ezek egyes regionális vonatkozásai.

Tér és Társadalom 16. évf. 2002/4. 1-24. p.

Hettne, B. (1995) Development Theory and the Three Worlds: Towards an International Political Economy of Development. Longman Scientific Publishers, London.

Hettne, B.-Inotai, A.-Sunkel, O. (eds.) (1999) Globalism and the New Regionalism. St. Martin's Press, New York.

Jones, B. (1995) Globalisation and Interdependence in the International Political Economy: Rhetoric and Reality. Pinter, London.

Jones, S.G. (1998) Information, Internet and Community: Notes Toward an Understanding of Community in the Information Age. - Jones, S.G. (ed.) Cybersociety 2.0: Revisiting ComputerMediated Communication and Community. SAGE Publications, London. 1-24. o.

Kratochwil, F. (1996) Citizenship on the Border of Order. - Lapid, Y.-Friedrich K. (eds.) The Return of Culture and ldentity in IR Theory. Lynne Rienner, Boulder, Colorado. 181-197. o.

Lenk, C. (1999) Electronic Support of Citizen Participation in Planning Processes. - Hague, B.N.Loader, B.D. (eds.) Digital Democracy: Discourse and Decision-Making in the Information Age. London, Routledge. 87-95. o.

Lijphart, A. (1977) Democracy and Plural Societies: A Comparative Exploration. Yale University Press, New Haven.

Mcgrew, A.G. (ed.) (1997) The Transformation of Democracy? Globalization and Territorial Democracy. Polity Press, Cambridge.

Miller, L. (1994) Global Order: Values and Power in International Politics. Westview Press, Boulder, Colorado.

Mul, J. de (1999) The Informatization of the Worldview. - Information, Communication and Society. Vol. 2.69-94. o.

Murden, S.W. (2002) Islam, the Middle East, and the New Global Hegemony. Lynne Rienner Publishers, London.

Negroponte, N. (1995) Being Digital. Hodder and Stoughton, London.

Niebuhr, R. (1965) Man's Nature and His Communities: Essays on the Dynamics and Enigmas of Man's Personal and Social Existence. University of California Press, Berkeley.

Paasi, A. (1986) The Institutionalization of Regions: A Theoretical Framework for Understanding the Emergence of Regions and the Constitution of Regional Identity. - Fennia. Vol. 164.

Preston, P.W. (1997) Political/Cultural ldentity: Citizens and Nations in a Global Era. SAGE Publications London.

Reidenberg, J.R. (1997) Governing Networks and Rule-Making in Cyberspace. - Kahin, B.- Nesson, Ch. (eds.) Borders in Cyberspace: Information Policy and the Global Information Infrastructure. MIT Press, Cambridge, Massachussets. 84-105. o.

Robertson, R. (1992) Globalization: Social Theory and Global Structure. SAGE Publications, London.

Ruggie, J.G. (1999) Territoriality and Beyond: Problematizing Modernity in International Relations. International Organization. 1. 139-174, o.

Schulz, M.-Söderbaum, F.-Öjendal, J. (eds.) (2001) Regionalization in a Globalizing World: A Comparative Perspective on Forms, Actors and Processes. ZED Books, London.

Schumpeter, J. (1939) Business Cycles: A Theoretical, Historical and Statistical Analysis of the Capitalist Process. Harvard University Press, Cambridge.

Short, J.R.-Yeong-Hyun, K. (1999) Globalization and the City. Longman, London.

Storper, M.-Thomadakidis, S.B.-Tsipouri, L.J. (eds.) (1994) Latecomers in the Global Economy. Routledge, London.

Szücs J. (1988) Vázlat Európa három történeti régiójáról. Magvetỏ Kiadó, Budapest

Taubner, G. (ed.) (1997) Global Law Without a State. Aldershot, Darthmouth.

Tsagarousianou, R.-Tambini, D.-Brian, C. (eds.) (1998) Cyberdemocracy: Technology, Cities and Civic Networks. Routledge, London.

Wilden, A. (1972) System and Structure: Essays in Communication and Exchange. Tavistock, London.

Wilhelm, A.G. (1999) Virtual Sounding Boards: How Deliberate Is Online Political Discussion? Hague, B.N.-Loader, B.D. (eds.) Digital Democracy: Discourse and Decision-Making in the Information Age. Routledge, London. 155-159. o. 


\section{GLOBALISATION, HEGEMONY AND THE POLITICAL REARRENGEMENT IN THE THIRD MILLENIUM, AND SOME REGIONAL ASPECTS OF THEM}

\section{VIKTOR SEGESVÁRY}

Basically, there are only two options regarding the institutional re-ordering of the political sphere in the future. The first of these options consists in maintaining the principles of the present political institution, the nation-state, but extending its territorial grasp either by creating a world state or by creating regional political entities which could be built up, like in a puzzle, into a world state. The main element in this first conception is, whatever the form of the path chosen, to replicate the nation-state formula at ever larger territorial levels thereby further eliminating any intermediary stages between the individual and the political institution, that is, totally disregarding the principle of subsidiarity and extending the bureaucratic domination of non-elected officials. Consequently, the democratic order looses its sense because one cannot speak of democracy when the system of national representation is replicated through representatives electing, in turn, less numerous and even less representative delegates at each institutional level, in a similar way as it is today in the United Nations. All cultural aspects of institution-founding communities will be lost; identity will simply mean to be a human being, traditions will be merged in an all-embracing world culture, and the human person will be nothing but one among billions, undistinguishable and without character. A multitude constituting the three necessary elements of late modern society - as producers, as consumers, and as a voting machine.

The second option, which represents an entirely new possibility for humanity, a possibility created by the hitherto unknown advances in technologies of communication and information, consists in the elimination of the nation-state and its replacement not by greater but by smaller units of political-institutional ordering. This solution would give priority to regional integration at a much more limited territorial basis than continents or sub-continents. Such an alternative world order of non-state political units will not be based on any preexisting principle, but follow people's natural inclination to stay together in institutional frameworks of the public sphere which suit their cultural, economic, traditional and way-oflife contexts. Not the territorial grasp, not the possibilities of control, not the unifying wills of certain individuals or groups would determine the size of these new communities but solely the affinities among populations living together in certain areas. In fact, such communities would not be regarded as constituted for eternity, but as living organisms which may change with time, with the modification of relevant contexts in the never-ending succession of generations, and with the fluctuating reality of life chances and opportunities of survival which are conditioned by the unfolding ecological drama from which we cannot escape, and which may inexorably transform the environment in some areas of the earth's surface. 